\title{
Language Learners' Willingness to Communicate and Speaking Anxiety in Online versus Face-to-Face Learning Contexts
}

\author{
Nada Alqarni \\ King Khalid University, Abha, Saudi Arabia \\ https://orcid.org/0000-0002-9238-2258
}

\begin{abstract}
Foreign language instruction has moved from face-to-face to online learning in response to the COVID-19 pandemic. This study aimed to explore the extent to which Foreign Language Classroom Enjoyment (FLCE), Foreign Language Speaking Anxiety (FLSA) and demographic variables (i.e., age, gender, and course grades) are linked to English as a Foreign Language (EFL) learners' Willingness to Communicate (WTC) in English under two conditions: online learning and conventional (face-toface) learning. The study sample consisted of 106 Saudi undergraduate EFL learners. The research instrument was an online questionnaire. The data were analysed quantitatively through $t$-tests, Pearson correlational tests, and a hierarchical regression analysis. The research findings indicated that: (1) higher levels of WTC were found in the online learning context than in the face-to-face context; (2) FLCE was a positive predictor, while FLSA was a negative predictor, of WTC in the online and face-toface learning contexts; (3) a high course grade seemed to be a positive predictor of EFL learners' WTC only in the online learning context. These findings imply that utilizing online-based learning, particularly in the context of developing speaking skills, may foster EFL learners' communication in the foreign language. Therefore, it is recommended that language teachers should support their students in practicing L2 communication during online classes in a more supportive atmosphere.
\end{abstract}

Keywords: willingness to communicate; speaking anxiety; classroom enjoyment; online learning; learner's psychology

\section{Introduction}

Several studies have examined language learners' affective states and how these have an impact on their foreign language communication and language use (Khajavy et al., 2018; MacIntyre \& Gregersen, 2012). In the context of language learning psychology, the term 'affect' refers to positive feelings, such as selfconfidence, motivation, enjoyment and willingness to communicate, or to negative feelings, such as language anxiety and boredom (MacIntyre \& 
Gregersen, 2012). Among the positive emotions, the willingness to communicate (WTC) in the second language has been the focus of several recent studies on Second Language Acquisition (SLA). It has been argued that preparing learners who are willing to communicate in the target language is one of the most significant goals of language instruction worldwide (Dewaele, 2019; Lee \& Hsieh, 2019; Wang et al., 2021). WTC can be defined as an individual's preference to speak without any pressure (MacIntyre, 2020).

In this study, WTC has been examined from two main perspectives. The first is a trait-like perspective whereby WTC is investigated alongside other affects, such as self-confidence in the Second Language (L2), language learning motivation (Yashima, 2012) and language anxiety (Hashimoto, 2002). The second perspective is dynamic and situated (Kang, 2005), whereby the influences of personal, contextual (i.e., learning environment, teacher support, classroom activities and topics) (Khajavy et al., 2018) and linguistic factors (Cao, 2011) are examined. Language learners show a wide range of individual differences regarding their WTC (Khajavy et al., 2018). However, there is still a literature gap on the extent to which WTC varies, depending on the type of language instruction setting, for example, face-to-face or online learning environments.

Language anxiety is one of the most affective reactions to language communication (MacIntyre \& Gregersen, 2012). Different types of language anxiety, namely writing, reading and speaking anxiety, are related to various language skills (MacIntyre \& Gregersen, 2012). In this study, the focus is limited to the impact of foreign language speaking anxiety (FLSA) on WTC. Although it has been argued that language anxiety plays a crucial role in predicting language learners' WTC, the role of positive emotions, such as foreign language classroom enjoyment (FLCE) (Khajavy et al., 2018), and the role of other contextual factors, such as the classroom environment, should be studied in terms of how they support or detract from WTC. Dewaele and MacIntyre (2014) have emphasized that enjoyment should be considered in the research literature in order to provide a balance with studies that have examined the role of negative emotions, such as foreign language anxiety. FLCE has been defined as "a complex emotion, capturing interacting dimensions of challenge and perceived ability that reflect the human drive for success in the face of difficult tasks." (Dewaele \& MacIntyre, 2016, p. 216).

Among the external variables linked to WTC are factors related to the learning environment, which are understood as "variables embedded in the immediate classroom environment that exerted influences on learners' WTC" (Cao, 2011, p. 471). Although previous studies have focused on the role of certain environmental factors, such as teacher support, peers and social interaction, in learners' WTC (e.g., Dewaele \& MacIntyre, 2014), the role of the type of communicative context - especially contexts utilizing technological devices - in WTC, FLSA and FLCE remains unexplored.

In the light of the current literature, the main assumption of this study is that if foreign language learners are situated in a language environment where there is 
a deliberate effort made to minimise student anxiety and which provides a pleasant learning atmosphere, they might be willing to speak in the target language. If these conditions are not met, learners would be unwilling to volunteer answers and communicate in the classroom (MacIntyre, 2020). Therefore, learners' positive emotions can help them absorb more linguistic input and more importantly, boost their ability to overcome the effects of negative emotions (Dewaele, 2021). The key question, however, is whether or not the levels of and the relationship between these variables differ when instructors are forced to switch their method of instruction to emergency remote teaching, as they were with the onset of the COVID-19 pandemic. This study attempts to answer this question.

While a growing body of previous studies has addressed FLSA, FLCE and WTC in conventional-traditional classroom settings, little research has specifically compared these variables in traditional versus online learning contexts in the case of undergraduate students. This study is an attempt to fill a gap in the FLSA and the WTC literature on undergraduate EFL learners. Thus, the purposes of this study are to focus on the impacts of both positive (i.e., FLCE) and negative emotions (i.e., FLSA) on WTC, taking into consideration the type of communicative context (face-to-face versus online learning), and to investigate the main predictors of WTC in both learning settings. The findings of this study might offer insights into how L2 teachers can utilize the learning context to develop their students' psychological states, thereby helping them become more willing to communicate in the foreign languages they are learning, particularly during the pandemic.

\section{Literature Review}

\subsection{Foreign language anxiety}

Existing research has focused on learner emotions, including both positive and negative types (enjoyment, frustration, boredom, hope, motivation, anxiety, shame and anger), in language education for some time. Among the negative emotions, language anxiety is the most affective reaction in terms of second language communication (MacIntyre \& Gregersen, 2012) and one of the main individual differences among language learners, as reported in SLA research (Dewaele, 2021). Generally, anxiety can be classified as follows as: (1) a stable personality trait that a person can have in a variety of situations; (2) state anxiety, which is considered a temporary state affected by a particular moment; and (3) situation-specific anxiety, which is more likely to occur in particular circumstances (MacIntyre, 2020). Language anxiety has been classified as situation specific, thereby occurring in language learning settings such as classrooms (MacIntyre, 2020).

As argued by MacIntyre and Gregersen (2012), certain feelings are associated with language anxiety, such as tension, nervousness, worry and being upset. Those "feelings associated with language anxiety typically precede avoidance or escape; we want to leave a situation that makes us anxious as a means of self-protection. We are at a risk in a situation where we cannot understand what is being said" (MacIntyre \& Gregersen, 2012, p. 195). Certain physiological reactions, such as 
sweating, blushing or a racing heart, and internal and behavioral reactions, such as self-deprecating thoughts, fidgeting, talking too much and stuttering, are also associated with language anxiety (Woodrow, 2006).

In a few studies, it has been argued that language anxiety can play a positive or a facilitative role in the learning process, for example, to keep learners alert and more focused (MacIntyre \& Gregersen, 2012; Woodrow, 2006). However, other studies have reported negative effects or the debilitating role of anxiety in language learning achievement (Dewaele, 2009). More specifically, one study found that more anxious students had lower course grades than those of their non-anxious counterparts (Dewaele, 2009). Anxious learners also avoided volunteering answers in the classroom, participated less, forgot previously learned language materials (MacIntyre \& Gregersen, 2012) and dropped out of the language course (Dewaele, 2009). Jiang and Dewaele (2019) found that Chinese undergraduate EFL learners reported higher levels of FLCA compared with other international students. The authors attributed this finding to the educational system in China, which is characterized as exam oriented, and to the relatively few opportunities for Chinese EFL learners to communicate with native English speakers.

The term 'language anxiety' encompasses feelings of worry or fear-related affective states that are usually associated with using/learning a foreign language (MacIntyre \& Gregersen, 2012). Additionally, language anxiety covers different language skills, namely speaking, writing and comprehension. In a qualitative study that explored the sources of FLSA among senior high school students in Indonesia, Mukminin et al. (2015) found that poor speaking skills, low self-esteem in relation to speaking English and fear of negative responses from the teacher and peers were the most common reasons. The authors also found other reasons, such as lack of English vocabulary and grammar skills as well as cultural influences on speaking English due to a more teacher-centered style in the language classroom. Woodrow (2006) found L2 speaking anxiety to be a significant predictor of oral achievement among 272 advanced English students in Australian universities. The author also reported causes of anxiety, such as interacting with native speakers.

\subsection{Foreign Language Classroom Enjoyment (FLCE)}

FLCE is the most studied positive emotion in recent SLA research (Piniel \& Albert, 2018). Csikszentmihalyi (2008) described enjoyment in its broad meaning as a sense of accomplishment experienced when someone achieves something unexpected. According to Fredrickson $(2004,2013)$ - the founder of the broadenand-build theory - positive emotions constitute an important factor for broadening people's momentary thought-action and attention capacities, building their personal resources for the future, promoting their resilience in difficult times and expanding their creativity in relation to problem solving. Based on this theory, MacIntyre and Gregersen (2012) added that learners' positive emotions can contribute to overcoming their negative emotions when learning/using L2. They also argued that positive emotions can boost the ability of learners to learn and process foreign languages. 
Research aims to explore the effects of certain learner variables, such as trait emotional intelligence (Li, 2020), WTC (Khajavy et al., 2018), foreign language anxiety (Dewaele \& MacIntyre, 2014; Jiang \& Dewaele, 2019) and learners' positive attitudes (Dewaele \& Dewaele, 2018), on FLCE. Dewaele and MacIntyre (2014) investigated the effects of learner variables, mainly anxiety, on FLCE, among a multilingual sample of 1746 learners in different multilingual contexts. The authors found that older learners who reached higher levels of academic achievement and had higher levels of foreign language proficiency tended to experience higher levels of FLCE. Moreover, they reported a moderate negative correlation between FLCE and FLCA, indicating a degree of interrelation yet independence between the two variables. Based on that evidence, Dewaele and MacIntyre (2014) conceptualized anxiety and enjoyment as two different emotions that might be negatively correlated rather than as opposite ends of a single continuum (i.e., extreme ends of the same construct). In a follow-up study on the same database, Dewaele and MacIntyre (2016) found that positive and negative emotions were essential in helping students regulate their emotions. They stated, "the goal is not to eliminate FLCA any more than a runner would wish to eliminate one of her feet (even the sore, aching one). Learners will find their balance when both feet, enjoyment and anxiety, are brought into equilibrium" (Dewaele \& MacIntyre, 2016, pp. 233-234). In their recent meta-analysis of 21 studies on the relationship between FLCE and FLCA, Botes et al. (2021) found a moderate negative correlation between the two dimensions. They concluded that language learners who experienced more enjoyment in the classroom tended to feel less anxious.

A few studies found that FLCE varied, depending on certain factors. For example, female students experienced more enjoyment than their male peers (Dewaele \& Dewaele, 2017). In their pseudo-longitudinal study, Dewaele and Dewaele (2017) investigated the changes in FLCE and FLCA over time among three groups of students from two British secondary schools. The authors found that the two constructs were stable over time, but FLCE was predicted by the students' attitudes towards both the foreign language and their teacher, as well as multilingualism. The role of multilingualism in predicting FLCE was also reported in some studies (Botes et al., 2020; Dewaele \& MacIntyre, 2014). Students' positive attitudes towards both the foreign language (De Smet et al., 2018) and their language teachers (Jiang \& Dewaele, 2019) were found to be linked to higher levels of FLCE. FLCE was predicted by levels of proficiency in the foreign language; advanced foreign language learners tended to experience higher levels of FLCE than beginner learners (Botes et al., 2020). Thus, the feeling of being fluent when speaking an L2 might help students feel proud in the classroom and allow them to initiate communication (Dewaele \& Alfawzan, 2018). A few researchers who focused on the relationship between FLCE and academic performance found that higher levels of academic achievement could be associated with higher levels of FLCE (Botes et al., 2020; Dewaele \& Alfawzan, 2018; Jiang \& Dewaele, 2019). FLCE thus seems to be "the fuel that drives the learning and it is strengthened and replenished by the performance and progress in the FL" (Dewaele, 2021, p. 20). 
Several studies also found that enjoyment was mediated by social interactions with friendly peers, supportive and humorous teachers, as well as an encouraging and positive classroom environment (Dewaele \& MacIntyre, 2014; Khajavy et al., 2018; Saito et al., 2018). Additionally, interesting and adequately challenging classroom activities could contribute to increasing students' enjoyment (Khajavy et al., 2018). The school context was reported be an important predictor of FLCE. Interestingly, Resnik and Dewaele (2021) found that students reported lower levels of FLCE when schools shifted to online learning during the pandemic. However, the relationship between these variables might not be based on causality but could be bi-directional. Thus, the relationships among FLSA, FLCE and WTC in different learning contexts remain unexplored.

\subsection{Willingness to communicate in a second language}

Early research on WTC showed that individual trait-like factors, such as selfconfidence, motivation and language anxiety, affected learners' WTC (Peng \& Woodrow, 2010; Yashima, 2002). MacIntyre (2020) argued that those students who were willing to communicate might feel self-confident in their conversations and answers. Accordingly, certain conditions (i.e., self-confidence, lack of anxiety and communicative competence) are crucial in order for language learners to volunteer answers in class. It has also been argued that WTC can be considered the main goal of language instruction, incorporating linguistic and communicative competence, along with other factors (MacIntyre, 2020). The evidence of this perspective was shown previously in an empirical study by MacIntyre and Legatto (2011), who found that participants attributed a decline in their dynamic WTC to their perceived lack of competence and inadequate vocabulary knowledge.

The central research question in several studies concerns the relationships between WTC and certain psychological variables such as FLCE and FLCA (Dewaele, 2019; Khajavy et al., 2018; Wang et al., 2021). In his quantitative study, Dewaele (2019) found that anxiety was the strongest negative predictor of WTC. He observed that enjoyment and frequency of foreign language use by teachers were positive predictors of WTC in a traditional face-to-face classroom. As suggested by Dewaele (2019), "creating a friendly and sufficiently challenging and interesting emotional classroom environment and picking conversation topics that match the students' interests" can boost students' WTC (p. 533). In their study on the role of social climate, language mindset and academic emotions (enjoyment, pride, anxiety and boredom) in predicting WTC among 811 Chinese college and university students, Wang et al. (2021) found that the effects of language mindset on WTC in class were fully mediated by academic emotions (enjoyment, pride and boredom). The effects of the social climate on WTC in class were fully mediated by the four academic emotions.

Khajavy et al. (2018) examined the role of enjoyment, anxiety and classroom environment (CE) in WTC among 1528 secondary school learners of English in Iran. Their findings showed that higher levels of WTC were positively associated with a positive classroom environment. They also found that higher levels of FLCE and lower levels of language anxiety were linked to higher WTC, indicating 
the role of enjoyment in predicting WTC. In a more recent study, Lee (2020) investigated the role of grit (perseverance in terms of effort and consistency of interest) and CE in learners' WTC. Three groups of Korean EFL learners, totaling 647 participants, were involved in that study. The findings showed that grit (when defined as perseverance in terms of effort) and CE were indicators of WTC, but grit (when defined as consistency of interest) was not predictive of learners' WTC. These findings suggest that FLCE may help students utilize more opportunities to speak English. The author also concluded that FLCE tended to play an important role in learners' L2 communication and enhanced their WTC.

As shown by previous studies, WTC appears to be mediated by several psychological and environmental factors. One of the environmental factors is the type of instruction, which seems to play a crucial role in motivating L2 learners to initiate communication in the L2 (Resnik \& Dewaele, 2021). The present study focuses specifically on the impact of the learning setting on WTC. A learning setting that needs to be considered is online learning compared with traditional learning.

\subsection{Online learning context}

Online learning refers to e-learning or virtual learning, which means delivering information or conducting instruction through the use of technology, primarily over the internet (Wang et al., 2010). During online classes, the interactive communication between teachers and students relies on the use of technological devices. In anticipating the spread of the COVID-19 pandemic, many educational institutions worldwide, including those in Saudi Arabia, decided to shift from offline to online learning to continue the teaching-learning process safely and securely. This required students to study from their homes through online classes.

Previous studies have shown that the classroom environment (conceptualized as involving teacher support, task orientation and student cohesiveness) might be a predictor of the psychological states of students (Cao, 2011). The classroom environment refers to "all the things that are present in the classroom that can affect individuals' engagement" (Khajavy et al., 2018, p. 6). The type of learning environment itself (e.g., conventional learning face-to-face versus online learning) can influence the positive or negative emotions of learners (Xiangming et al., 2020; Zhang et al., 2021). In their experimental study, Rahimi and Soleymani (2015) explored the effects of using a mobile learning device (to access podcasts) on practicing listening skills and the levels of listening anxiety among EFL learners. The researchers compared the levels of listening anxiety between 25 participants in the control group and 25 participants in the experimental group. Their findings showed reduced listening anxiety and enhanced listening comprehension in the experimental group after the experiment. The researchers concluded that "computer-based learning environments have been found to contribute to more successful listening" and could also provide students with more opportunities to listen in informal situations (p. 157). In their study using a qualitative design, Reinders and Wattana (2015) discussed EFL students' perspectives on their emotions in a digital game environment. The students reported that they were more reticent because they often felt worried about making grammatical errors 
and being judged negatively by their teachers and peers in an English language classroom. In contrast, in a digital game environment (where the students used pseudonyms and avatars while playing with others), they were more likely to feel safe and relaxed when interacting using English.

In relation to the impact of online learning on language learners' emotions, some studies have reported that learners' emotions tend to change, depending on the communicative context. For example, Xiangming et al. (2020) conducted a longitudinal study on 158 postgraduate language learners to investigate the changes in language anxiety levels over a 10-week period in a technology-assisted learning setting (the mobile learning app for the Rain Classroom). The researchers found that the learners felt less anxious about language learning in the technology-assisted learning setting. They also noticed that the students developed positive attitudes towards learning technology, participated more and showed a heightened awareness of their learning progress. Xiangming et al. (2020, p. 9) reported that "In the technology-based surroundings, students felt more secure and relaxed when interacting with the technology tool or with other peers via the technology tool". A study by Zhang et al. (2021) focused on language learners' enjoyment and emotional regulation in an online collaborative learning environment. Their findings showed that the participants used different types of emotional regulation (self-, co- and socially shared) to achieve learning enjoyment through collaborative online learning. Furthermore, the effects of automatic speech recognition-based websites on Indonesian EFL learners' vocabulary knowledge, enjoyment and speaking anxiety were assessed by Bashori et al. (2021). Their findings revealed that using websites successfully increased the students' knowledge of vocabulary, reduced their speaking anxiety and stimulated their enjoyment.

Lee and Hsieh (2019) explored the relationships between affective variables (second language self-confidence, anxiety, motivation and grit) and WTC in inclass, out-of-class and digital environments among 261 Taiwanese undergraduate EFL students. The quantitative data showed that the students with higher levels of grit and self-confidence had higher levels of WTC in all three communicative settings. The researchers reasoned that if EFL learners remain steadfast and persistent in their language learning and confident about their L2 communication, they are more likely to initiate communication despite the type of communicative setting. They also found that a lack of anxiety could be an important predictor of students' WTC in a non-digital environment but not in the digital context. This interesting finding needs to be backed up with further empirical evidence.

Until now, a large body of research has focused on language learners' psychological states in traditional classroom learning, where they often talk with their teachers and peers in a relatively predictable face-to-face L2 scenario (e.g., Dewaele \& Dewaele, 2017; Yu, 2011). However, probing into rapidly emerging elearning contexts, in which learners communicate in the L2 through technological devices, as well as their effects on students' WCT, speaking anxiety and enjoyment remains unexplored. 


\section{Research Methodology}

\subsection{Research goal}

This study investigated the impacts of FLSA, FLCE and demographic variables on EFL learners' WTC in English in face-to-face versus online learning environments. Specifically, it seeks to answer the following questions:

1. Is there a difference in the levels of WTC, FLSA and FLCE between face-toface and online learning contexts?

2. To what extent do FLSA and FLCE correlate with WTC in face-to-face and online learning contexts?

3. Which demographic variables (i.e., age, course grades, FLSA and FLCE) are significant predictors of EFL students' WTC in face-to-face and online learning contexts?

\subsection{Context and participation}

A total of 106 EFL university students (36 males and 70 females) from the English language department at King Khalid University, Saudi Arabia, participated in this study. Their ages ranged from 19 to 24 years $(M=20.88, S D=1.28)$. All participants were Saudi citizens with no overseas experience. All participants spoke the Arabic language as their native language while they were studying EFL. With respect to their academic 5-point grading scores, they had the following GPAs: $4.51-5$ (64\% of the participants), $4.01-4.50$ (24\%), 3.51-4 (6\%), 3.01-3.50 (5\%) and below 3.01 ( $1 \%$ of the participants). ${ }^{1}$

Generally, Saudi university students in the English department were placed in different classes and levels (levels 1 to 8), taking English courses for a maximum of 24 hours per week. The English language courses varied in terms of their content, covering reading, writing, listening and speaking to more advanced courses in linguistics, applied linguistics, English literature and Arabic-English translation. Only the students who were above level 3 were included in this study because it aimed to examine the students' self-perception of their WTC concerning their FLAS and FLCE when learning the English language in two contexts: faceto-face and online.

At the time of this study, the participants were taking online English courses (elearning) during the COVID-19 pandemic. Before COVID-19, the students had attended traditional face-to-face classes for at least three semesters. Thus, all the participants had experienced both learning contexts.

\subsection{Instrumentation}

This study adopted a cross-sectional design using online questionnaires distributed to the participants.

\footnotetext{
${ }^{1}$ GPA means grade point average, which is a number that indicates the score that students have achieved in their college courses on average. According to the Saudi Arabian higher education grading system, a 0-5 grading scale has the following levels: 4.76-5 (exceptional), 4.51-4.75 (excellent), 4.01-4.50 (superior), 3.51-4 (very good), 3.01-3.50 (above average), 2.51-3 (good), 2.012.50 (high pass), $1.01-2$ (pass) and 0-1 (fail).
} 
The main instrument used in this study was an online questionnaire that consisted of three main parts: (1) demographic information; (2) questions on the traditional face-to-face learning setting (WTC, FLSA and FLCE); and (3) questions on the online learning setting (WTC, FLSA and FLCE). Table 1 gives a detailed description of the instrument used.

\subsection{Procedure}

The study was carried out during the summer term of the 2020-2021 academic year. The participants were recruited through a snowball sampling technique, which is a form of non-probability sampling (Rooney \& Ness Evans, 2018). This technique was achieved by asking participants to share the online survey via their university email accounts with their classmates who were EFL students. One of the advantages of an online questionnaire is that it allows the collection of large amounts of data from participants within a short time (Dörnyei, 2007). However, one of the disadvantages of using a questionnaire is that it does not allow complex meaning or causes of factors (Dörnyei, 2007) to be explored. Since the main purpose of this study was to explore the interrelationships between the variables, the quantitative approach was adopted.

To ensure the validity of the questionnaire, each item was presented in Arabic and in English in order to allow participants to confirm their understanding of the content of the scales. The online survey took about 15 minutes to complete. Instructions were given at the beginning of the survey, and confidentiality and anonymity were ensured to encourage honest responses. Participation was voluntary. The questionnaire was translated into the Arabic language by the author and rechecked by a proficient bilingual Arabic-English translator. The questionnaire was also assessed by two experts who agreed that it was a valid measure. All the scales used in this study had previously been used in several other studies (see Table 1), and had been determined as being valid and reliable to measure the constructs. The research design and the questionnaire obtained ethical approval from the ethics board at the author's research institution. 
Table 1: A detailed description of the instrument used in this study

\begin{tabular}{|c|c|c|c|c|c|}
\hline & Variables & $\begin{array}{l}\text { No. } \\
\text { of } \\
\text { items }\end{array}$ & Example item & $\begin{array}{l}\text { Rating } \\
\text { scale }\end{array}$ & Reference \\
\hline $\begin{array}{l}\text { Part 1: } \\
\text { Demographic } \\
\text { information }\end{array}$ & $\begin{array}{l}\text { Age, } \\
\text { gender, } \\
\text { and } \\
\text { academic } \\
\text { GPA } \\
\text { grade }\end{array}$ & 3 & $\begin{array}{l}\text { What is your } \\
\text { academic GPA } \\
\text { grade? }\end{array}$ & $\begin{array}{l}\text { Short } \\
\text { answer } \\
\text { questions }\end{array}$ & 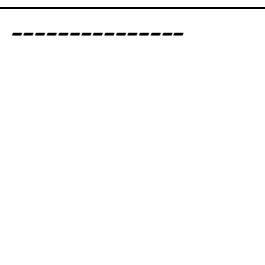 \\
\hline \multirow[t]{3}{*}{$\begin{array}{l}\text { Part 2: } \\
\text { Face-to-face } \\
\text { learning } \\
\text { setting }\end{array}$} & 1) WTC & 5 & $\begin{array}{l}\text { When are you } \\
\text { given a chance } \\
\text { to talk freely in } \\
\text { an English } \\
\text { (face-to-face) } \\
\text { class? }\end{array}$ & $\begin{array}{l}1= \\
\text { definitely } \\
\text { not willing } \\
\text { to } 5= \\
\text { definitely } \\
\text { willing } \\
\end{array}$ & $\begin{array}{l}\text { (Dewaele, 2019; } \\
\text { Wang et al., } \\
\text { 2021) }\end{array}$ \\
\hline & 2) FLSA & 18 & $\begin{array}{l}\text { I never feel } \\
\text { quite sure of } \\
\text { myself when I } \\
\text { am speaking in } \\
\text { my English } \\
\text { (face-to-face) } \\
\text { class. }\end{array}$ & $\begin{array}{l}1=\text { strongly } \\
\text { disagree to } \\
5=\text { strongly } \\
\text { agree }\end{array}$ & $\begin{array}{l}\text { (Woodrow, } \\
2006)\end{array}$ \\
\hline & 3) FLCE & 6 & $\begin{array}{l}\text { The face-to-face } \\
\text { English class } \\
\text { has a positive } \\
\text { environment. }\end{array}$ & $\begin{array}{l}1= \\
\text { definitely } \\
\text { not willing } \\
\text { to } 5= \\
\text { definitely } \\
\text { willing }\end{array}$ & $\begin{array}{l}\text { (Lee, 2020; } \\
\text { Dewaele \& } \\
\text { MacIntyre,2014) }\end{array}$ \\
\hline \multirow[t]{3}{*}{$\begin{array}{l}\text { Part 3: } \\
\text { Online } \\
\text { learning } \\
\text { setting }\end{array}$} & 1) WTC & 5 & $\begin{array}{l}\text { When are you } \\
\text { given a chance } \\
\text { to talk freely in } \\
\text { an English } \\
\text { (online) class? }\end{array}$ & $\begin{array}{l}1= \\
\text { definitely } \\
\text { not willing } \\
\text { to } 5= \\
\text { definitely } \\
\text { willing }\end{array}$ & ---- \\
\hline & 2) FLSA & 18 & $\begin{array}{l}\text { I never feel } \\
\text { quite sure of } \\
\text { myself when I } \\
\text { am speaking in } \\
\text { my English } \\
\text { (online) class. }\end{array}$ & $\begin{array}{l}1=\text { strongly } \\
\text { disagree to } \\
5=\text { strongly } \\
\text { agree }\end{array}$ & 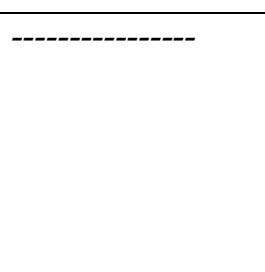 \\
\hline & 3) FLCE & 6 & $\begin{array}{l}\text { The online } \\
\text { English class } \\
\text { has a positive } \\
\text { environment }\end{array}$ & $\begin{array}{l}1= \\
\text { definitely } \\
\text { not willing } \\
\text { to } 5= \\
\text { definitely } \\
\text { willing }\end{array}$ & - \\
\hline
\end{tabular}

\subsection{Data analysis}

Before the statistical analysis, the data were statistically analyzed for reliability. Cronbach's alpha for the WTC scale was good ( $\alpha=.93$ in the face-to-face learning context and $\alpha=.90$ in the online learning context). The reliability estimates for 
FLSA and FLCE in both learning contexts were also good. To test the normality of the scores for the dependent variable (i.e., WTC), the difference between the WTC scores in the online and the face-to-face learning contexts was computed, and then, the normality of this new score was checked using the Shapiro-Wilk test ${ }^{2}$ (see Field, 2009, p. 329 for more details about the assumption of normality in the case of dependent $t$-tests). Based on the Shapiro-Wilk test results, the data were normally distributed (statistics $=.981, p=.135$ ); therefore, parametric tests could be used for the data analyses. A paired $t$-test was performed to find out the differences between the scores for each variable (i.e., WTC, FLSA and FLCE) in the two learning contexts. To examine the impacts of the independent variables (FLSA, FLCE, age, gender and course grades) on the main dependent variable (WTC) in both learning contexts, the quantitative data were analyzed statistically using hierarchical regression analyses separately in the two contexts. Pearson correlational tests were also performed to examine how FLSA and FLCE were linked to WTC in both contexts. All statistical calculations in this research were performed using the Statistical Package for the Social Sciences (SPSS, version 21).

\section{Results}

\subsection{Descriptive data for WTC, FLSA and FLCE in the face-to-face and online learning settings}

Table 2 demonstrates that the participants reported above-neutral levels of WTC $(M=3.26, S D=1.29 ; M=3.68, S D=1.08)$ and FLCE $(M=3.59, S D=1.15 ; M=3.70$, $S D=1.04)$ in the face-to-face and the online learning contexts, respectively. The mean score was above 3 (neutral agreement) on a five-point Likert scale. This result indicated that EFL learners generally had high levels of WTC and FLCE in both learning contexts. Interestingly, the results indicated that the mean score for FLSA in the online EFL context $(M=2.89, S D=.88)$ was lower than that in the face-to-face EFL context $(M=3.01, S D=.89)$, indicating that the participants reported lower levels of FLSA during online classes than face-to-face classes. There were no significant differences between males and females regarding their WTC, FLSA and FLCE in both learning settings.

Table 2: Descriptive data for the WTC, FLSA and FLCE variables in the two settings $(N=106)$

\begin{tabular}{|l|c|c|c|c|}
\hline EFL context & Variables & Mean & Std. deviation & $\boldsymbol{\alpha}$ \\
\hline \multirow{3}{*}{$\begin{array}{l}\text { Face-to-face } \\
\text { learning }\end{array}$} & WTC & 3.26 & 1.29 & .93 \\
\cline { 2 - 5 } & FLSA & 3.01 & .89 & .91 \\
\cline { 2 - 5 } $\begin{array}{l}\text { Online } \\
\text { learning }\end{array}$ & FLCE & 3.59 & 1.15 & .92 \\
\cline { 2 - 5 } & WTC & 3.68 & 1.08 & .90 \\
\cline { 2 - 5 } & FLSA & 2.89 & .88 & .90 \\
\hline
\end{tabular}

Note $:$ WTC $=$ Willingness to Communicate, FLSA = Foreign Language Speaking Anxiety, FLCE = Foreign Language Classroom Enjoyment,$\alpha=$ Cronbach's Alpha

\footnotetext{
${ }^{2}$ According to Field (2009, p. 221), "the predictors do not need to be normally distributed".
} 


\subsection{The statistical comparisons between WTC, FLSA and FLCE in the face-to- face and online learning settings}

Paired sample $t$-tests and correlational tests were conducted to find out the differences and the correlations between the variables in both learning contexts. First, the statistical analysis showed that the participants self-reported significantly higher WTC scores in the online learning setting $(M=3.68, S E=.125)$ than in the face-to-face learning setting $(M=3.26, S E=.104), t(105)=-2.39, p=.01$ (see Table 3). There was a negative correlation between the WTC scores in both learning contexts although it was not statistically significant (see Table 3). Second, the results did not show any difference between the mean scores for FLSA and FLCE in both learning contexts. Interestingly, the results indicated a positive and significant correlation between the FLSA levels in the face-to-face and the online learning contexts $(r=.341, p<.001)$, indicating that those participants who reported high levels of speaking anxiety in the face-to-face learning context did the same in the online context (see Table 3).

Table 3: Paired sample t-tests for WTC, FLSA and FLCE variables in the two learning settings $(N=106)$

\begin{tabular}{|c|c|c|c|c|c|c|c|}
\hline & \multicolumn{7}{|c|}{ Paired differences } \\
\cline { 2 - 8 } & Mean & $\begin{array}{c}\text { Std. } \\
\text { deviation }\end{array}$ & $\begin{array}{c}\text { Std. } \\
\text { error } \\
\text { mean }\end{array}$ & $t$ & $\begin{array}{c}\text { Sig. (2- } \\
\text { tailed) }\end{array}$ & $\begin{array}{c}\text { Correlat } \\
\text { ion }\end{array}$ & Sig \\
\hline $\begin{array}{c}\text { Pair 1 WTC } \\
\text { (face-to-face)- } \\
\text { WTC (online) }\end{array}$ & -0.420 & 1.81 & 0.175 & $-\mathbf{2 . 3 9 2}$ & 0.019 & -0.155 & .112 \\
\hline $\begin{array}{c}\text { Pair 2 FLSA } \\
\text { (face-to-face)- } \\
\text { FLSA (online) }\end{array}$ & 0.120 & 1.02 & 0.099 & 1.218 & 0.226 & $\mathbf{0 . 3 4 1}$ & .000 \\
\hline $\begin{array}{c}\text { Pair 3 FLCE } \\
\text { (face-to-face)- } \\
\text { FLCE (online) }\end{array}$ & -0.108 & 1.64 & 0.159 & -0.679 & 0.499 & -0.115 & .241 \\
\hline
\end{tabular}

Note: $d f=105$.

\subsubsection{The correlational analyses of WTC, FLSA and FLCE in the face-to-face and online learning settings}

As presented in Table 4, WTC in the face-to-face learning context had a negative and significant correlation with FLSA and a positive and significant correlation with FLCE. These results indicated that the EFL students who reported high levels of WTC reported low levels of speaking anxiety and high levels of enjoyment in the face-to-face learning context. The correlation analysis also showed a negative and statistically significant relationship between FLSA and FLCE $(r=-.0523, p<$ $.001)$ in the face-to-face learning context. This result revealed that the participants with high levels of FLSA might have low levels of FLCE.

Similarly, the Pearson correlational analysis between WTC in the online learning context and FLSA and FLCE showed a negative and significant link between WTC and FLSA $(r=-.628, p<.001)$. Meanwhile, a positive and significant link between WTC and FLCE $(r=.646, p<.001)$ was found. There was a negative and significant relationship between FLSA and FLCE $(r=-.379, p<.001)$ in the online learning 
context. These results indicated that the EFL students with high levels of FLSA seemed to have lower levels of WTC, as well as FLCE, during online classes.

Table 4: Pearson correlational analyses between WTC, FLSA and FLCE in the two settings $(N=106)$

\begin{tabular}{|c|c|c|c|}
\hline \multirow{6}{*}{$\begin{array}{l}\text { Pearson's } \\
\text { correlation } \\
\text { coefficient }\end{array}$} & $\begin{array}{l}\text { Face-to-face } \\
\text { learning } \\
\text { context }\end{array}$ & $\begin{array}{l}\text { FLSA (Face-to-face learning } \\
\text { context) }\end{array}$ & $\begin{array}{l}\text { FLCE (Face-to-face } \\
\text { learning context) }\end{array}$ \\
\hline & WTC & $-0.754^{* *}$ & $0.701^{* *}$ \\
\hline & FLSA & ------- & $-0.523^{* *}$ \\
\hline & $\begin{array}{l}\text { Online } \\
\text { learning } \\
\text { context }\end{array}$ & FLSA (online learning context) & $\begin{array}{l}\text { FLCE (online } \\
\text { learning context) }\end{array}$ \\
\hline & WTC & $-0.628^{* *}$ & $0.646^{* *}$ \\
\hline & FLSA & -ב---"- & $-0.379^{* *}$ \\
\hline
\end{tabular}

\subsection{Predictors of EFL students' WTC in the face-to-face and online learning contexts}

\subsubsection{Face-to-face EFL learning context}

The regression analysis produced a sample multiple correlation coefficient of 0.84 , indicating that approximately $71.4 \%$ of the total variance in the WTC levels in the face-to-face learning context could be explained by the predictor variables, $F(4$, $105)=63.01, p<.001$. In the first block, the age and the course grade were slightly significant $(p<.01)$, explaining $7.8 \%$ of the total variance (see Table 5$)$. In the second block, the effects of FLSA and FLCE were strongly significant, $\beta=-.509$ and .435 , respectively, all $p s<.001$. More specifically, this model accounted for $63.6 \%$ of the variance. Thus, as shown in Table 4 , FLSA $(B=-.73)$ was a negative predictor of WTC, while FLCE $(B=0.489)$ was a positive predictor of WTC in the face-to-face learning context.

Table 5: Hierarchical regression model for predicting WTC in the face-to-face learning environment $(N=106)$

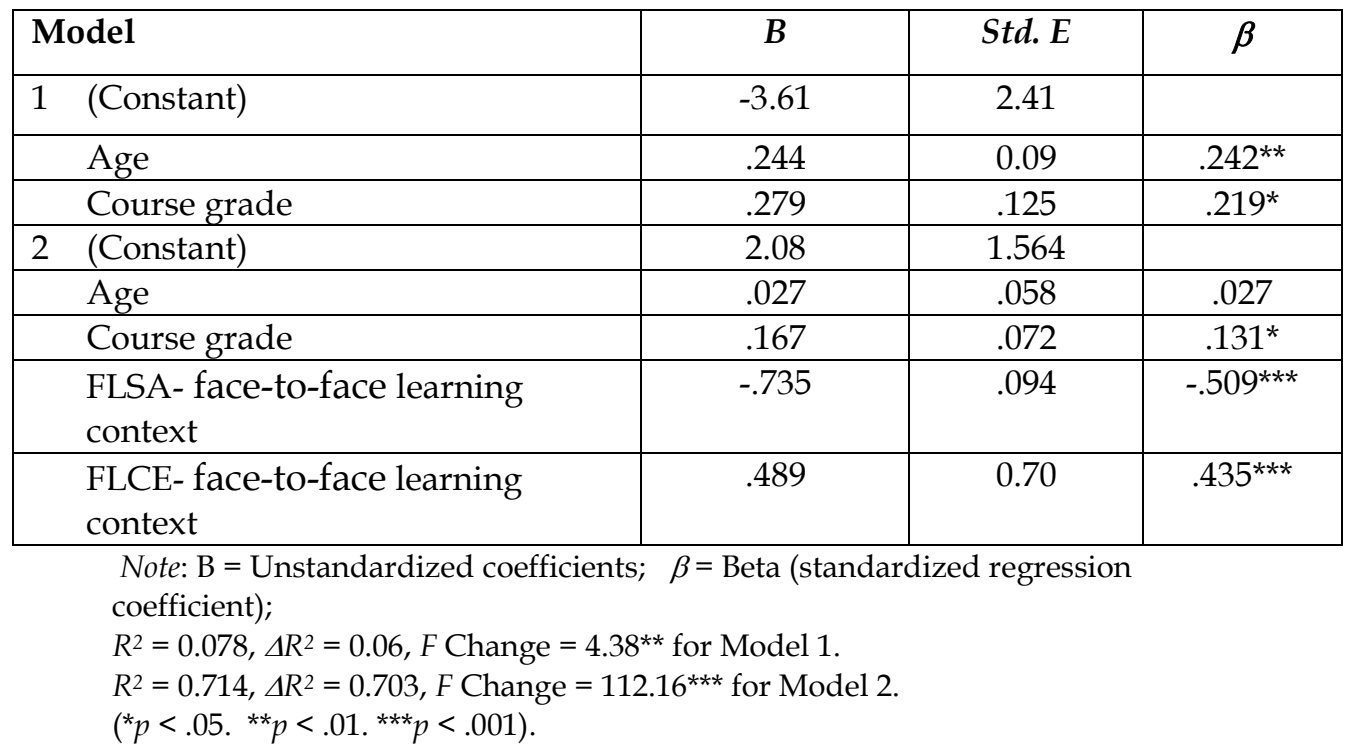




\subsubsection{Online EFL learning context}

The regression analysis produced a sample multiple correlation coefficient of 0.77 , indicating that approximately $60 \%$ of the total variance in the WTC levels in the online learning context could be explained by the predictor variables, $F(4,105)=$ $37.64, p<.001$. In the first block, the age and the course grade were not significant, explaining only $4 \%$ of the total variance (see Table 6 ). In the second block, the effects of FLSA and FLCE were strongly significant, $\beta=-.461$ and 0.45 , respectively, all $p s<.001$. More specifically, this model accounted for $55.9 \%$ of the variance. Thus, as shown in Table 5 , FLSA $(B=-.563)$ was a negative predictor of WTC, while FLCE $(B=.464)$ was a positive predictor of WTC in the online learning context.

Table 6: Hierarchical regression model for predicting WTC in the online learning environment $(N=106)$

\begin{tabular}{|ll|c|c|c|}
\hline Model & $\boldsymbol{B}$ & Std. $\boldsymbol{E}$ & $\boldsymbol{\beta}$ \\
\hline $1 \quad$ (Constant) & 4.450 & 2.046 & \\
\hline \multicolumn{2}{|c|}{ Age } & -0.085 & 0.084 & -0.101 \\
\hline Course grade & 0.159 & 0.106 & 0.150 \\
\hline \multicolumn{2}{|l|}{ (Constant) } & 4.954 & 1.541 & \\
\hline \multicolumn{2}{|l|}{ Course grade } & -0.076 & 0.057 & -0.091 \\
\hline $\begin{array}{l}\text { FLSA - in online learning } \\
\text { context }\end{array}$ & 0.037 & 0.070 & 0.034 \\
\hline $\begin{array}{l}\text { FLCE - in online learning } \\
\text { context }\end{array}$ & -0.563 & 0.085 & $-.0 .461^{* * *}$ \\
\hline
\end{tabular}

Note: $R^{2}=0.040, \Delta R^{2}=0.022, F$ Change $=2.17$ for Model 1 . $R^{2}=0.599, \Delta R^{2}=0.583, F$ Change $=70.205^{\star * *}$ for Model 2. $\left({ }^{*} p<.05 .{ }^{* *} p<.01 .{ }^{* * *} p<.001\right)$

\section{Discussion}

This study sought to advance the understanding of how foreign language anxiety and enjoyment are linked to EFL university students' WTC in traditional face-toface and online learning settings. The data yielded the following results: first, the participants self-reported higher WTC scores in the online setting than in the faceto-face learning setting. This finding suggests that those EFL learners who might be unwilling to initiate L2 communication in the traditional classroom might be willing to do so during online learning. This suggests that online-based communication might encourage students to initiate communication in their L2. This finding reflects Lee and Hsieh's (2019) suggestion that generally, the digital environment could help students feel more comfortable communicating in and using their L2. It can also be speculated that EFL learners tend to prefer to initiate communication and speak in online classes than in face-to-face classes. Today, individuals are more likely to rely on digital media for communication in their daily lives, in both their L1 and L2, which may, in turn, enhance their WTC, even during their learning process.

Second, the results revealed that the mean scores of FLSA in the face-to-face and the online learning environments were very similar $(M=3.10$ and $M=2.89$, respectively). In other words, EFL learners who experience high levels of FLSA in 
the classroom may still have that negative psychological state even during online classes.

Third, the correlational results regarding the link between WTC and FLSA and FLCE in both learning settings revealed that FLSA had a negative association with WTC in both learning contexts. Thus, EFL learners with high levels of FLSA might have low WTC levels, regardless of the learning context. This finding supports the findings of other studies, conducted in conventional-traditional classrooms, which found that speaking anxiety might be the main obstacle to fostering WTC (Dewaele, 2019; Khajavy et al., 2018). This study's results confirm previous findings but in another learning context, which is online-based learning. As has been discussed before, these findings may be attributed to several external or internal factors. For example, language learners may have fears of being negatively evaluated by peers or teachers or being corrected if they make mistakes when speaking. A closer analysis of the data revealed that the participants selfreported a high mean anxiety score $(M=4.01, S D=1.06)$ in the item "I feel very self-conscious about speaking English in front of other students" in the online learning setting. They also self-reported a high mean score in the same item in the face-to-face learning setting $(M=3.46, S D=1.28)$. The participants also had a high mean score in the item "I am afraid that my English teacher is ready to correct every mistake I make" $(M=3.59, S D=1.37)$ during online classes. Thus, it can be speculated that the fear of making mistakes orally and the fear of a negative evaluation from peers may significantly contribute to an increase in students' speaking anxiety, which, in turn, decreases their WTC.

However, enjoyment might increase the willingness to initiate communication in the classroom or during online-based learning. This suggests that EFL students who maintain their enjoyment when learning their L2 are more likely to initiate interaction in the classroom. This interpretation is supported by previous studies (e.g., Khajavy et al., 2018) that have reported enjoyment as an important factor for increasing students' WTC. Thus, enjoyable classroom activities under supportive conditions might facilitate students' L2 communication (Khajavy et al., 2018; Yashima, 2002). Moreover, an enjoyable classroom can provide a learning environment that fosters social bonds and interpersonal relationships among language learners (Dewaele \& MacIntyre, 2014). The role of FLCE in fostering WTC in different learning environments therefore emerges clearly from the data in this study.

When considering the impacts of FLSA and FLCE on WTC in the two learning contexts, the regression analysis demonstrated that FLSA was a negative predictor of WTC in both contexts, while FLCE was a positive predictor of WTC in both contexts. This echoes the findings of Khajavy et al. (2018) and Peng and Woodrow (2010), who reported that an enjoyable classroom (e.g., the English teacher is supportive, and the classroom is encouraging) results in a greater interest in providing the students with more opportunities to speak English and become more relaxed and less anxious. However, to the best of the author's knowledge, the current study is the first research that shows a positive association between FLCE and WTC, as well as a negative association between FLSA and 
WTC, among EFL university students in an online learning environment. Thus, this study adds to the previous literature on the foreign language learning process and communication, which indicates that a positive classroom atmosphere might help students overcome their psychological difficulties, such as L2 speaking anxiety (Dewaele \& Dewaele, 2018; Khajavy et al., 2018; Saito et al., 2018), and encourage them to speak using foreign languages in both online learning and traditional classroom settings. In this regard, the significant role of positive emotions (e.g., enjoyment) and negative emotions (e.g., anxiety) in WTC and language use in different contexts, both inside and outside the classroom, merit further investigation.

Interestingly, the results indicate that course grades might constitute a positive predictor of WTC only in the online learning setting. As college grades in most Saudi universities are based on performance-based examinations, university students are generally required to obtain high GPA scores to apply for jobs. Thus, it is not surprising that students with high grades might be motivated to communicate and practice using their target language in the classroom.

However, this result was observed in the online learning setting, indicating that digital technologies could foster students' WTC, as well as providing them with more opportunities to speak English and practice communication with others. This finding is a new contribution in the field of research on the foreign language learning process and communication.

\section{Conclusion}

The current study has examined the extent to which FLCE, FLSA and demographic variables are linked to EFL learners' WTC under two conditions: online and during conventional learning. The results indicate that EFL learners tend to have greater WTC during online classes than in conventional ones. This shows that digital technology can foster EFL learners' WTC and help them practice foreign language communication. However, the effectiveness of using technology in language learning might depend on external (e.g., classroom atmosphere or the teaching style) or internal factors (e.g., the language learner's personality). The findings also suggest that EFL learners who maintain their interest and enjoyment in learning English may have higher WTC levels, regardless of the context of EFL learning. Additionally, the present data provide evidence that WTC in online and traditional classroom settings may be affected by speaking anxiety. Theoretically, these findings uphold an emerging view of the role that language learners' psychological states can play in second language teaching and learning. As more data are generated on the internal and external factors that influence L2 communication and use, language teachers or researchers gain greater understanding of WTC and speaking anxiety.

\section{Pedagogical Implications}

The results of this study have several pedagogical implications for foreign language teachers and researchers. The first implication is that language teachers should support their students in practicing L2 communication during online classes. They should also develop their technical skills to utilize different 
technological tools that would help students perceive their L2 use as taking place in a more supportive atmosphere. Second, students, specifically those with low language proficiency levels, need to be encouraged to foster their WTC and practice L2 communication in different contexts. Online courses should be employed to delve deeper into how students' feelings and expectations maximize their language performance and use. Third, teachers ought to integrate different technological devices (e.g., online websites or audio/video materials) into the classroom activities in order to help students enjoy the classroom and increase their WTC (Peng, 2012). Fourth, teachers could deliver information to students focusing on the importance of managing their negative emotions, such as speaking anxiety, in fostering their communication in the target language. Teachers can also increase enjoyable tasks and activities through which students would have additional opportunities to put in more effort to speak English. Since speaking anxiety negatively predicts low WTC levels in both online and traditional classrooms, teachers should be more tolerant of students' speech errors, particularly when the focus is on fluency, not accuracy. They could change their teaching styles, based on their students' communicative needs, to foster students' WTC. At the institutional level, administrators could give language teachers more autonomy in terms of designing online activities and tasks to help students practice their L2 use in a non-threatening manner.

However, as with any research, there are certain areas for improvement in this study. First, since the present findings are based on correlational analyses, the study only supports the statistical link between the independent variables (FLCE, speaking anxiety and demographic variables) and the dependent variable (WTC in English in two settings: online and traditional learning classrooms). In other words, the current data cannot provide any evidence of a causal relationship between the variables. Second, the nature of the study sample - Saudi EFL learners from one university - makes the interpretation of the results limited to this context; they cannot be generalized to other EFL contexts. Thus, future experimental or longitudinal studies are needed to understand how these variables influence one another in different contexts, with a large number of participants. Qualitative studies are also necessary to delve deeper into foreign language learners' psychological states during the online learning process to obtain nuanced details about L2 communication and speaking anxiety.

\section{Declaration of conflicting interest}

The author(s) declared no potential conflicts of interest with respect to the research, authorship, and/or publication of this article.

\section{Funding}

The author(s) received no financial support for the research, authorship, and/or publication of this article.

\section{References}

Bashori, M., van Hout, R., Strik, H., \& Cucchiarini, C. (2021). Effects of ASR-based websites on EFL learners' vocabulary, speaking anxiety, and language enjoyment. System, 99, 1-16. https://doi.org/10.1016/j.system.2021.102496 
Botes, E., Dewaele, J.-M., \& Greiff, S. (2020). The power to improve: Effects of multilingualism and perceived proficiency on enjoyment and anxiety in foreign language learning. European Journal of Applied Linguistics, 8(2), 1-28. https://doi.org/10.1515/eujal-2020-0003

Botes, E., Dewaele, J.-M., \& Greiff, S. (2021). Taking stock: An overview of the literature and a preliminary meta-analysis of Foreign Language Enjoyment and other individual difference variables. Unpublished manuscript. http://doi.org/10.31234/osf.io/guaj5

Cao, Y. (2011). Investigating situational willingness to communicate within second language classrooms from an ecological perspective. System, 39(4), 468-479. https://doi.org/10.1016/j.system.2011.10.016

Csikszentmihalyi, M. (2008). Flow: The psychology of optimal experience. New York: Harper Perennial. https://doi.org/10.1075/idj.16.1.11bos

De Smet, A., Mettewie, L., Galand, B., Hiligsmann, P., \& Van Mensel, L. (2018). Classroom anxiety and enjoyment in CLIL and non-CLIL: Does the target language matter? Studies in Second Language Learning and Teaching, 8(1), 47-71. https://doi.org/10.14746/ssllt.2018.8.1.3

Dewaele, J. M. (2009). Individual differences in second language acquisition. In W. C. Ritchie \& T. K. Bhatia (Eds.), The new handbook of second language acquisition (pp. 623-640). United Kingdom: Emerald Group Publishing Limited. https://doi.org/10.1016/b978-012589042-7/50003-7

Dewaele, J. M. (2019). The effect of classroom emotions, attitudes toward English, and teacher behavior on willingness to communicate among English foreign language learners. Journal of Language and Social Psychology,38(4), 523-535. https://doi.org/10.1177/0261927X19864996

Dewaele, J. M. (2021) Enjoyment. In S. Li, P. Hiver \& M. Papi (Eds.), The Routledge Handbook of Second Language Acquisition and Individual Differences. United Kingdom, London: Routledge.

Dewaele, J. M. \& Alfawzan, M. (2018). Does the effect of enjoyment outweigh that of anxiety in foreign language performance? In J.-M. Dewaele (Guest Ed.), Special issue Emotions in SLA. Studies in Second Language Learning and Teaching, 8, 21-45. https://doi.org/10.14746/ssllt.2018.8.1.2

Dewaele, J. M., \& Dewaele, L. (2017). The dynamic interactions in foreign language classroom anxiety and foreign language enjoyment of pupils aged 12 to 18 . A pseudo-longitudinal investigation. Journal of the European Second Language Association, 1(1), 12-22. http:// doi.org/10.22599/jesla.6

Dewaele, J. M., \& Dewaele, L. (2018). Learner-internal and learner-external predictors of willingness to communicate in the FL classroom. Journal of the European Second Language Association, 2(1), 24-37. https:// doi.org/10.22599/jesla.37.

Dewaele, J. M., \& MacIntyre, P. D. (2014). The two faces of Janus? Anxiety and enjoyment in the foreign language classroom. Studies in second language learning and teaching, 4(2), 237-274. https://doi.org/10.14746/ssllt.2014.4.2.5.

Dewaele, J. M., \& MacIntyre, P.D. (2016). Foreign language enjoyment and foreign language classroom anxiety: The right and left feet of FL learning? In P.D. MacIntyre, T. Gregersen, \& S. Mercer (Eds.), Positive Psychology in SLA (pp. 215236). United Kingdom, Bristol: Multilingual Matters. https://doi.org/10.21832/9781783095360-010

Dörnyei, Z. (2007). Research methods in applied linguistics: Quantitative, qualitative and mixed methodologies. United Kingdom, Oxford: Oxford University Press.

Field, A. (2009). Discovering statistics using SPSS. UK, London: Sage publications. 
Fredrickson, B. (2004). The broaden-and-build theory of positive emotions. Philosophical Transactions of the Royal Society, 359(1449), 1367-1377. https://doi.org/10.1098/rstb.2004.1512

Fredrickson, B. L. (2013). Updated thinking on positivity ratios. American Psychologist, 68, 814-822. https://doi.org/10.1037/a0033584

Hashimoto, Y. (2002). Motivation and willingness to communicate as predictors of reported L2 use: the Japanese ESL context. Second Language Studies, 20(2), 29-70. http:// doi.org/10125/40649

Jiang, Y., \& Dewaele, J. M. (2019). How unique is the foreign language classroom enjoyment and anxiety of Chinese EFL learners?. System, 82, 13-25. https://doi.org/10.1016/j.system.2019.02.017

Kang, S. J. (2005). Dynamic emergence of situational willingness to communicate in a second language. System, 33(2), https://doi.org/10.1016/j.system.2004.10.004

Khajavy, G. H., MacIntyre, P. D., \& Barabadi, E. (2018). Role of the emotions and classroom environment in willingness to communicate: Applying doubly latent multilevel analysis in second language acquisition research. Studies in Second Language Acquisition, 40(3), 605-624. https://doi.org/10.1017/s0272263117000304

Lee, J. S. (2020). The role of grit and classroom enjoyment in EFL learners' willingness to communicate. Journal of Multilingual and Multicultural Development, 1-17. https:// doi.org/10.1080/01434632.2020.1746319

Lee, J. S., \& Hsieh, J. C. (2019). Affective variables and willingness to communicate of EFL learners in in-class, out-of-class, and digital contexts. System, 82, 63-73. https://doi.org/10.1016/j.system.2019.03.002

Li, C. (2020). A positive psychology perspective on Chinese EFL students' trait emotional intelligence, foreign language enjoyment and EFL learning achievement. Journal of Multilingual and Multicultural Development, 41(3), 246-263. https://doi.org/10.1080/01434632.2019.1614187

MacIntyre, P. (2020). Expanding the theoretical base for the dynamics of willingness to communicate. Studies in Second Language Learning and Teaching, 10(1), 111-131. https://doi.org/10.14746/ssllt.2020.10.1.6

MacIntyre, P. D., \& Legatto, J. J. (2011). A dynamic system approach to willingness to communicate: Developing an idiodynamic method to capture rapidly changing affect. Applied Linguistics, 32(2),

149-171. https://doi.org/10.1093/applin/amq037

MacIntyre, P.D., \& Gregersen, T. (2012). Emotions that facilitate language learning: The positive broadening power of the imagination. Studies in Second Language Learning and Teaching, 2, 193-213. https:// doi.org/10.14746/ssllt.2012.2.2.4

Mukminin, A., Masbirorotni, M., Noprival, N., Sutarno, S., Arif, N., \& Maimunah, M. (2015). EFL speaking anxiety among senior high school students and policy recommendations. Journal of Education and Learning, 9(3), 217-225. https://doi.org/10.11591/edulearn.v9i3.1828

Peng, J. E. (2012). Towards an ecological understanding of willingness to communicate in EFL classrooms in China. System, 40(2), 203-213. https://doi.org/10.1016/j.system.2012.02.002

Peng, J. E., \& Woodrow, L. (2010). Willingness to communicate in English: A model in the Chinese EFL classroom context. Language learning,60(4), 834-876. https://doi.org/10.1111/j.1467-9922.2010.00576.x

Piniel, K., \& Albert, Á. (2018). Advanced learners' foreign language-related emotions across the four skills. Studies in Second Language Learning and Teaching, 8(1), 127147._https://doi.org/10.14746/ssllt.2018.8.1.6 
Rahimi, M., \& Soleymani, E. (2015). The impact of mobile learning on listening anxiety and listening comprehension. English Language Teaching, 8(10), 152-161. http://doi.org/10.5539/elt.v8n10p152

Reinders, H., \& Wattana, S. (2015). Affect and willingness to communicate in digital gamebased learning. ReCALL, 27(1),

38-57. https://doi.org/10.1017/s0958344014000226

Resnik, P., \& Dewaele, J.-M. (2021). Learner emotions, autonomy and trait emotional intelligence in 'in-person' versus emergency remote English foreign language teaching in Europe. Applied Linguistics Review (in press). https://doi.org/10.1515/applirev-2020-0096

Rooney, B. J., \& Ness Evans, A. (2018). Methods in psychological research. United Kingdom, London: Sage Publications. https://doi.org/10.4135/9781506384955

Wang, H., Peng, A., \& Patterson, M. M. (2021). The roles of class social climate, language mindset, and emotions in predicting willingness to communicate in a foreign language. System, 99, 102529. https://doi.org/10.1016/j.system.2021.102529

Wang, M., Ran, W., Liao, J., \& Yang, S. J. (2010). A performance-oriented approach to elearning in the workplace. Journal of Educational Technology \& Society, 13(4), 167179. https://www.jstor.org/stable/jeductechsoci.13.4.167

Woodrow, L. (2006). Anxiety and speaking English as a second language. RELC journal, 37(3), 308-328. https:// doi.org/10.1177/0033688206071315

Xiangming, L., Liu, M., \& Zhang, C. (2020). Technological impact on language anxiety $\begin{array}{llll}\text { dynamic. Computers } & \mathcal{E} & 103839 .\end{array}$ https://doi.org/10.1016/j.compedu.2020.103839

Yashima, T. (2002). Willingness to communicate in a second language: The Japanese EFL context. The Modern Language Journal, 86(1), 54-66. https:/ / doi.org/10.1111/15404781.00136

Yashima, T. (2012). Willingness to communicate: Momentary volition that results in L2 behaviour. In S. Mercer, S. Ryan, \& M. Williams (Eds.), Psychology for language learning: Insights from research, theory and practice (pp. 119-135). United Kingdom, London: Palgrave Macmillan. https://doi.org/10.1057/9781137032829_9

$\mathrm{Yu}$, M. (2011). Effect of communication variables, affective variables, and teacher immediacy on willingness to communicate of foreign language learners. Chinese Journal of Communication, 4(02), 218-236. https://doi.org/10.1080/17544750.2011.565678

Zhang, Z., Liu, T., \& Lee, C. B. (2021). Language learners' enjoyment and emotion regulation in online collaborative learning. System, 98, 102478. https://doi.org/10.1016/j.system.2021.102478 